\title{
WOUND HEALING ACTIVITY OF LEMON PEPPER ESSENTIAL OIL IN BURN WOUND OF WISTAR RAT
}

\author{
DEWI PURNAMA ${ }^{1 *}$, CHRISMIS NOVALINDA GINTING ${ }^{2}$, LINDA CHIUMAN ${ }^{3}$, ADRIAN KHU $^{2}$
}

${ }^{1}$ Magister Program of Biomedical Sciences, Universitas Prima Indonesia, Medan, Indonesia. ${ }^{2}$ Department of Public Health, Faculty of Medicine, Universitas Prima Indonesia, North Sumatera, Indonesia. ${ }^{3}$ Faculty of Medicine, Universitas Prima Indonesia, Medan, Indonesia. Email: dewipurnama.unpri@gmail.com

Received: 25 March 2021, Revised and Accepted: 05 May 2021

ABSTRACT

Objective: The purpose of the study was to investigate the acceleration of the wound healing properties from lemon pepper's essential oil as the lemon pepper's ointment.

Methods: There were 20 Wistar rats as an animal trial divided into four sample groups, including control (ointment base), standard (Nebacetin ${ }^{\circledR}$ ), $5 \%$ lemon pepper, and $10 \%$ lemon pepper ointment, and all groups were injured by electric soldier for $10 \mathrm{~s}$. The wound contraction and epithelialization period were the parameters of wound healing activity.

Result: Wound contraction as the parameter of wound healing showed significant difference between the standard and lemon pepper ointment $(\mathrm{p}<0.05)$. The lemon pepper ointment groups showed no significant wound contraction difference in each lemon pepper ointment concentration at the initial time of observation, however, it become more obvious at last period of observation. Furthermore, the epithelialization period did not showed any significant differences between standard, $5 \%$ or $10 \%$ lemon pepper ointment against the control group ( $\mathrm{p}>0.05$ ).

Conclusion: It can be concluded that the lemon pepper ointment had the potential to accelerate wound healing activity.

Keywords: Epithelialization period, Lemon pepper, Ointment, Wound contraction.

(C) 2021 The Authors. Published by Innovare Academic Sciences Pvt Ltd. This is an open access article under the CC BY license (http://creativecommons.org/ licenses/by/4.0/) DOI: http://dx.doi.org/10.22159/ajpcr.2021v14i5.41598. Journal homepage: https://innovareacademics.in/journals/index.php/ajpcr

\section{INTRODUCTION}

The most common and severe type of injuries is burn injury that leads to significant morbidity and mortality over the world. The case of burn is found high in the low and middle-income countries account for $90 \%$ of burn cases and around 5-12\% of all types of injuries in the world. Furthermore, burn was fourth leading cause of injury after road traffic injuries, falls, and violence [1-3].

According to the World Health Organization (WHO) data, around 265,000 people die every year because of burn injuries. Around twothirds of burn injuries were found in the African, East Mediterranean, and Southeast Asia regions. The East Mediterranean and Southeast Asia regions' annual incidence rate is around 187 and 243/100,000. On the other hand, burn injury is the leading cause of disability-adjusted lifeyears lost in low- and middle-income countries [1,2].

Some studies have been performed to evaluate the incidence of burn injuries in Indonesia which have not been available yet. Health Ministry of Indonesia at 2007 as Basic Health Research reported that the burn wound's prevalence was $2.2 \%$. Even though, some local studies looked for incidence of burn injuries. One of them was Primadina research, who reported that 35 patients to suffer from burn in the plastic surgery department of Syarif Ambami Rato Ebhu Government Hospital during 2015-2016 that aged ranged from 41 years old to 60 years old [4]. Other studies performed by Suzan and Andayani who reported that the extended dehydration because of the burn injuries could cause some morbidities such as acute kidney injury, septic shock, liver function reduction, or amputation [5].

Due to these reasons, it was needed a novel drug or substance which promote acceleration the wound healing process, especially the burn wound, to improve the loss of disability-adjusted life-years and to reduce the number of burn injury. Several potential natural sources promote improvement the wound healing properties in Indonesia. Indonesia is a tropical region which enriched by various herbs. One of these was lemon pepper that has a scientific name as Zanthoxylum acanthopodium DC. None studies have been performed to explore the wound healing properties of lemon pepper. Nevertheless, some in vitro studies have been explored the phytochemical content and other pharmacology properties from crude extract activities of lemon pepper. Finally, this study was performed to investigate the health benefit of lemon pepper's essential oil as the ointment to accelerate the burn wound healing process that used the Wistar rats as the animal trial.

\section{METHODS}

This study used pre-test and post-test only control group design as an experimental study in Riwandi Animal House during October 2019November 2019. The lemon pepper fruit as the sample was obtained from a traditional market in the Medan, North Sumatera. This study has been approved by Health Research Ethics Committee from Universitas Prima Indonesia with registration no. 001/KEPK/UNPRI/IX/2020.

The essential oil was obtained from the lemon pepper fruit by hydrodistillation methods. Amount of $600 \mathrm{~g}$ of fresh lemon pepper was distilled by distillation apparatus for $4 \mathrm{~h}$ at $80^{\circ} \mathrm{C}$. Moreover, the distillate was precipitate by anhydrous sodium sulfate, then it was filtered, and the filtrate as the essential oil was collected. The essential oil volume and weight were documented to determine the yield by dividing the volume of obtained essential oil into the fresh lemon pepper mass and then multiple $100 \%$ [6].

On the other hand, the fresh lemon pepper was also screened for the phytochemical included flavonoid, tannin, alkaloid, phenol, steroid/ triterpenoid, terpenoid, and saponin $[7,8]$. Moreover, the essential oil of 
lemon pepper was used to formulate the ointment. The formulation of the lemon pepper ointment and base of ointment is shown in Table 1.

Twenty male Wistar rats were used to evaluate the wound healing properties and these rats were grouped into four different groups:

a. Control: The rats were applied by ointment base once a day every day.

b. Standard: The rats were applied by Nebacetin ${ }^{\circledR}$ ointment (neomycin sulfate and bacitracin) once day every day.

c. $5 \%$ lemon pepper ointment: The rats were applied by $5 \%$ lemon pepper ointment once every day.

d. $10 \%$ lemon pepper ointment: The rats were applied by $10 \%$ lemon pepper ointment once a day every day.

At the beginning evaluation for wound healing activity, all the male Wistar rats were injured by the modified electric soldier for $10 \mathrm{~s}$ in the rats' dorsal which had been shaved. All animal trials were injected intramuscular by $50 \mathrm{mg} / \mathrm{Kg}$ body weight of ketamine. However, all animal trials had been fasting for around $12 \mathrm{~h}$ before the injection [9-11]. The evaluation was finished when the eschar had been exfoliated spontaneously and observed every 2-4 days.

Evaluation of the wound healing activity used two different parameters, namely, wound contraction and epithelialization period. The wound contraction was calculated by the initial and specific width of the burn wound measured by the ruler. The wound contraction (\%) was determined by dividing the difference of initial and specific burn wound width into the burn wound's initial width and then multiples $100 \%$. Meanwhile, the epithelialization period was the time which was required by the eschar to exfoliate naturally [10].

All data were analyzed according to the normality of data. If data were normal, it would be analyzed by one-way ANOVA and express as Mean \pm SD. As the opposite, if the data were not normal, it would be analyzed by Kruskal-Wallis and expressed as median (range). The Shapiro-Wilk determined the normality of data. The ANOVA and Kruskal-Wallis were continued by the post hoc test and Mann-Whitney, respectively.

\section{RESULTS}

The essential oil obtained has some characteristics such as initial weight, weight of essential oil, volume of essential oil, and yield. The amount of $600 \mathrm{~g}$ fresh lemon pepper as the initial weight was distilled and produced $1.5 \mathrm{ml}$ essential oil (1.54 g). Based on these data, the yield of essential oil was $0.25 \%$. On the other hand, this study also performed phytochemical screening against fresh lemon pepper, and the fresh lemon pepper had some phytochemicals like alkaloid.

According to Table 2, the fresh lemon pepper has some phytochemicals such as alkaloid, flavonoid, and tannin. Moreover, this study was continued by the evaluation of wound healing activity. The wound healing parameter data must be initially analyzed the normality.

According to Table 3 , the $6^{\text {th }}$ day and $9^{\text {th }}$ day wound contraction were normal. It was shown by $\mathrm{p}<0.05$. ANOVA or Kruskal-Wallis then continued the analysis to look for the association between treatment groups and the wound healing activity parameter. The result of the analysis is shown in Table 4.

Table 1: Formulation of lemon pepper fruit ointment

\begin{tabular}{llll}
\hline Materials & Ointment base (g) & \multicolumn{2}{l}{$\begin{array}{l}\text { Lemon pepper } \\
\text { ointment }\end{array}$} \\
\cline { 3 - 4 } & & $\mathbf{5 \%}$ & $\mathbf{1 0 \%}$ \\
\hline Lemon pepper essential oil & - & $0.5 \mathrm{ml}$ & $1 \mathrm{ml}$ \\
Lanolin & 2.5 & $2.5 \mathrm{~g}$ & $2.5 \mathrm{~g}$ \\
Hard paraffin & 2.5 & $2.5 \mathrm{~g}$ & $2.5 \mathrm{~g}$ \\
Cetostearyl alcohol & 2.5 & $2.5 \mathrm{~g}$ & $2.5 \mathrm{~g}$ \\
White Vaseline & 42.5 & $42.5 \mathrm{~g}$ & $42.5 \mathrm{~g}$ \\
\hline
\end{tabular}

According to Table 4, wound contraction from each observation showed a significant difference. The superscript showed the result of the post hoc test and Mann-Whitney at the end of data on Table 5, and it showed significant differences in wound contraction between control groups with the other groups. However, there was a significant difference in wound contraction between the standard and lemon pepper ointment during the evaluation. Meanwhile, the rats that received lemon pepper ointment showed no significant wound contraction difference between $5 \%$ and $10 \%$ lemon pepper ointment at the initial time of observation, but the significant differences were observed at the last period of observation. Moreover, Fig. 1 shows the comparison of wound contraction among each group of rats.

According to Fig. 1, the highest wound contraction was found in $10 \%$ lemon pepper ointment, followed by $5 \%$ lemon pepper ointment, standard group, and the last control group. The difference in wound contraction also became clearer day to day.

Another parameter was also evaluated was the epithelialization period. Kruskal-Wallis and Mann-Whitney analyzed the epithelialization period of rats. The analysis of epithelialization period is shown in Table 5 .

According to Table 5, there was a significant difference between standard, $5 \%$ and $10 \%$ lemon pepper ointment against the control group. However, there was no significant difference that was observed between standard and lemon pepper ointment.

\section{DISCUSSION}

The yield of the essential oil in this study was $0.25 \%$. This study shows a similar result to the previous study. Rienoviar and Setyaningsih (2018) reported that the yield from ethanol, ethyl acetate:ethyl acetate (1:1) extract of lemon pepper was $6.54 \%, 5.35 \%$, and $6.09 \%$, respectively. The essential oil has better quality than the extract of lemon pepper due to the yield of essential oil was lower than the extract. The yield value was inversely correlated with quality [12].

Moreover, the phytochemical screening showed that lemon pepper fruit contains various phytochemicals. This study was showed a similar result to the previous study. Saragih and Arsita reported that the fresh lemon pepper from Toba Samosir and North Tapanuli had phenolic, saponin, flavonoid, tannin, triterpenoid, and alkaloid [13]. On the other hand, ethanol extract of lemon pepper's leaf also contains alkaloid, steroid, and saponin. According to these data, it can be concluded that the lemon pepper's leaf had fewer phytochemicals than the fruits [14].

Table 2: Screening phytochemical of fresh lemon pepper fruit

\begin{tabular}{llc}
\hline Phytochemicals & Methods & Result \\
\hline Alkaloid & Dragendorff's & + \\
& Mayer & + \\
Steroid & Salkowski & - \\
Saponin & Aquadest & - \\
& Aquadest+96\% alcohol & - \\
Flavonoid & $5 \% \mathrm{FeCl}_{3}$ & + \\
& $10 \% \mathrm{NaOH}^{2}$ & - \\
Tannin & $\mathrm{FeCl} 3$ & + \\
\hline
\end{tabular}

Table 3: The normality of wound healing parameter

\begin{tabular}{ll}
\hline Parameter & p-value \\
\hline $3^{\text {rd }}$ day wound contraction & $0.009^{*}$ \\
$6^{\text {th }}$ day wound contraction & 0.353 \\
$9^{\text {th }}$ day wound contraction & 0.057 \\
$12^{\text {th }}$ day wound contraction & $0.035^{*}$ \\
$14^{\text {th }}$ day wound contraction & $0.001^{*}$ \\
Epithelialization period & $0.001^{*}$ \\
\hline
\end{tabular}

*p-value $<0.05$, the data were normal 
Table 4: Association between the groups of treatment and wound contraction every observation day

\begin{tabular}{|c|c|c|c|c|c|}
\hline \multirow[t]{3}{*}{ Observation } & \multicolumn{4}{|c|}{ Wound contraction (\%) } & \multirow[t]{3}{*}{ p-value } \\
\hline & \multirow[t]{2}{*}{ Control } & \multirow[t]{2}{*}{ Standard } & \multicolumn{2}{|c|}{ Lemon pepper ointment } & \\
\hline & & & $5 \%$ & $10 \%$ & \\
\hline $3^{\text {rd }}$ day & $4.76(8.33)$ & $0.00(8.70)$ & $13.64(25.91)^{\mathrm{ab}}$ & $10.71(15.91)^{\mathrm{ab}}$ & $0.002^{* *}$ \\
\hline $6^{\text {th }}$ day & $9.36 \pm 5.21$ & $18.72 \pm 10.54$ & $30.08 \pm 7.88^{\mathrm{a}}$ & $35.67 \pm 7.58^{\mathrm{ab}}$ & $0.000^{*}$ \\
\hline $9^{\text {th }}$ day & $7.59 \pm 7.92^{b}$ & $35.91 \pm 8.05^{a}$ & $46.95 \pm 6.55^{\mathrm{a}}$ & $51.42 \pm 8.92^{\mathrm{ab}}$ & $0.000^{*}$ \\
\hline $12^{\text {th }}$ day & $9.52\left(29.17^{\mathrm{b}}\right.$ & $55.56(20.71)^{\mathrm{a}}$ & $63.64(21.75)^{\mathrm{a}}$ & $66.67(8.96)^{\mathrm{a}}$ & $0.004^{* *}$ \\
\hline
\end{tabular}

*Data were expressed as Mean \pm SD, and $P$ value was obtained by one-way ANOVA and post hoc test Tukey HSD. ${ }^{* *}$ Data were expressed as median (range), and $P$ value was obtained by Kruskal-Wallis and Mann-Whitney. ${ }^{\text {It }}$ was showed a significant difference against control. ${ }^{b}$ It was showed a significant difference against standard

Table 5: Comparison of epithelialization period among groups of treatment

\begin{tabular}{lll}
\hline Group & $\begin{array}{l}\text { Epithelialization } \\
\text { period* }^{*}\end{array}$ & p-values \\
\hline Control & $22(2)^{\mathrm{a}}$ & 0.033 \\
Standard & $18(2)^{\mathrm{b}}$ & \\
$5 \%$ lemon pepper ointment & $20(2)^{\mathrm{b}}$ & \\
10\% lemon pepper & $20(2)^{\mathrm{b}}$ & \\
ointment & & \\
\hline
\end{tabular}

*Data were expressed as median (range). Different superscript in the same column showed a significant difference at $P<0.05$

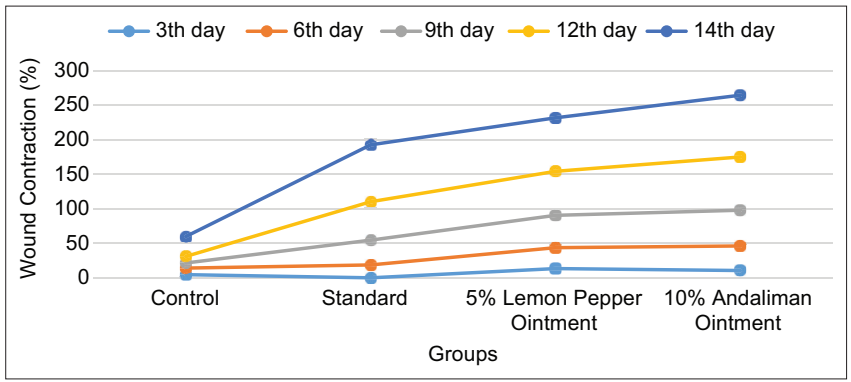

Fig. 1: Average of wound contraction among the groups of treatment as long as observation period

It was obvious that the lemon pepper fruit had more phytochemical than the leaf. Moreover, based on the essential oil yield, the essential oil has better quality than the extract. Hence, this study evaluates the lemon pepper fruit essential oil as the ointment. Based on the result of the evaluation, the lemon pepper ointment can accelerate the wound healing process.

The result of this study has answered the purpose of this study. It was shown by the improvement of the wound contraction and epithelialization period among groups of treatment. The wound contraction increased significantly, followed by observation duration; however, the difference in ointment concentration did not affect the wound contraction earlier but at last. Meanwhile, the epithelialization period did not significantly differ against the standard group, but they showed a difference among the control group.

The obvious study that explores the wound healing effect of lemon pepper was not available yet. However, several studies explore other pharmacological properties that supported the potential wound healing effect of lemon pepper ointment. These pharmacological properties include antioxidant, anti-inflammatory, and antimicrobial that create a better microenvironment to accelerate the wound healing process. Winarti et al. reported that ethyl acetate extract of lemon pepper has high antioxidant activity with $\mathrm{IC}_{50}$ value $66.91 \mathrm{BPJ}$, due to the presence 2-metoksi-4-vinilfenol [15]. Yanti et al. also reported that the ethanol extract of lemon pepper had anti-inflammatory activity by significantly inhibiting the expression of several biomarkers of inflammation at the level of protein synthesis (tumor necrosis factor-alpha [TNF- $\alpha$ ], protein cyclooxygenase [COX-2], and matrix metallopeptidase-9 [MMP-9]) and gene (TNF- $\alpha$, IL-6, iNOS, COX-2, and MMP-9) against the macrophage that was induced by lipopolysaccharide [16]. Meanwhile, several studies reported the antimicrobial activity of lemon pepper against some pathogens such as Staphylococcus aureus, Escherichia coli, Bacillus cereus, Bacillus stearothermophilus, Pseudomonas aeruginosa, Vibrio cholera, and Salmonella typhimurium through in vitro study [17-20].

\section{CONCLUSION}

Overall, the lemon pepper ointment accelerates burn wound healing effects compared to standard groups. The higher concentration ointment was not showed a significant difference at the initial administration.

\section{ACKNOWLEDGMENTS}

The author(s) disclosed receipts of the support for the research and/or publication of this article.

\section{AUTHORS' CONTRIBUTION}

Dewi Purnama - Writing manuscript, concept and designing the study, data collection, data analysis, and interpretation of data. Chrismis Novalinda Ginting, Linda Chiuman, and Adrian Khu - Editing and revision of the manuscript, and final approval.

\section{AUTHORS' FUNDING}

All authors did not receive any specific funding for this study.

\section{CONFLICTS OF INTEREST}

The authors declare that there were no conflicts of interest.

\section{REFERENCES}

1. Tripathee S, Basnet SJ. Epidemiology of burn injuries in Nepal: A systemic review. Burns Trauma 2017;5:10.

2. Rehman S, Tabasum S, Khalid FA, Raza S, Mehrose MY, Shahzad I, et al. The distribution and determinants of burn injuries at jinnah burn and reconstructive surgery centre, lahore. Proceedings 2018;32:31-5.

3. ALfadli M, El-Sehsah EM, Ramadan MA. Risk factors and distribution of MDROs among patients with healthcare associated burn wound infection. Germs 2018;8:199-206.

4. Primadina N. Epidemiologi kasus bedah plastik di rsud syarifah ambami rato ebhu Bangkalan, penelitian retrospektif dua tahun. Med Health Sci J 2018;1:41-6.

5. Suzan R, Andayani DE. Tata laksana nutrisi pada pasien luka bakar listrik. JMJ 2017;5:1-13.

6. Begum M, Lyngdoh W, Sharma HK. Formulation and evaluation of mosquito repellent ointment prepared with the essential oil of Zanthoxylum acanthopodium DC. Indigenous to Northeast India. Int J Green Pharm 2018;12:518-27.

7. Widowati W, Wargasetia TL, Afifah E, Mozef T, Kusuma HS, Nufus H, et al. Antioxidant and antidiabetic potential of Curcuma longa and its compounds. Asian J Agric Biol 2018;6:149-61. 
8. Widowati W, Rani AP, Hamzah RA, Arumwardana S, Afifah E, Kusuma HW, et al. Antioxidant and antiaging assays of Hibiscus sabdariffa extract and its compounds. Nat Prod Sci 2017;23:192-200.

9. Darmalaksana IG, Sudimantini LM, Jayawarditha AA, Dada IK. Gerusan daun pegagan mempercepat kesembuhan luka bakar pada tikus putih. Bul Vet Udayana 2018;10:137.

10. Thakur R, Jain N, Pathak R, Sandhu SS. Practices in wound healing studies of plants. Evid Based Complement Alternat Med 2011:2011:438056.

11. Verma DK, Bharat M, Nayak D, Shanbhag T, Shanbhag V, Rajput RS. Areca catechu: Effect of topical ethanolic extract on burn wound healing in albino rats. Int J Pharmacol Clin Sci 2012;1:74-8.

12. Rienoviar, Setyaningsih D. Studi senyawa aroma ekstrak andaliman (Zanthoxylum acanthopodium) dari beberapa pelarut menggunakan gas chromatography-mass spectra (GC-MS). War Ind Has Pertan 2018;35:85-90.

13. Saragih DE, Arsita EV. The phytochemical content of Zanthoxylum acanthopodium and its potential as a medicinal plant in the regions of Toba Samosir and North Tapanuli, North Sumatra. Pros Semin Nas Masy Biodiversitas Indones 2019;5:71-6.

14. Batubara MS, Sabri E, Tanjung M. Pengaruh pemberian ekstrak etanol daun andaliman (Zanthoxylum acanthopodium DC.) terhadap gambaran morfologi ovarium mencit (Mus musculus L.) strain DDW. Klorofil 2017;1:5-10.

15. Winarti W, Simanjuntak P, Syahidin MF. Identifikasi senyawa kimia aktif antioksidan dari ekstrak etil asetat buah andaliman (Zanthoxylum acanthopodium DC). In: Talenta Conference Series: Tropical Medicine (TM). Vol. 1. Indonesia: Talenta Publisher; 2018. p. 162-6.

16. Yanti, Pramudito TE, Nuriasari N, Juliana K. Lemon pepper fruit extract (Zanthoxylum acanthopodium DC.) suppresses the expression of inflammatory mediators in lipopolysaccharide-induced macrophages in vitro. Am J Biochem Biotechnol 2011;7:190-5.

17. Parhusip AJ. Kajian Mekanisme Antibakteri Ekstrak Andaliman (Zanthoxylum acanthopodium) Terhadap Bakteri Patogen Pangan; 2006.

18. Sitanggang FM, Duniaji AS, Pratiwi ID. Daya hambat ekstrak buah andaliman (Zanthoxylum acanthopodium DC) dalam etil asetat terhadap pertumbuhan Escherichia coli. J Ilmu Teknol Pangan 2019;8:257-66.

19. Muzafri A. Uji aktivitas antimikroba ekstrak andaliman (Zanthoxylum acanthopodium DC.) pada Staphylococcus aureus. J Sungkai 2019;7:122-6

20. Asbur YK. Pemanfaatan andaliman (Zanthoxylum acanthopodium DC) sebagai tanaman penghasil minyak atsiri. J Kultiv 2018;17:537-43. 